\title{
SOME EVOLUTIONS OF THE ROMANIAN IT MARKET
}

\author{
Laura Cătălina Țimiraș \\ "Vasile Alecsandri” University of Bacau \\ timiras.laura@ub.ro
}

\begin{abstract}
IT market in Romania registered a positive trend, estimations regarding the evolution for the next period indicating the same trend. This development was implicit in conjunction with the growing interest of population and organizations for getting the economic and social benefits offered by information technology, the expansion of the market and the increasing in the use IT by organizations and population empowering reciprocally. In this context, the contribution of the industry of "Information and communications" has increased in overall macroeconomic indicators and in the total employed population at the national level.
\end{abstract}

\section{Keywords}

IT market; Internet; population

\section{JEL Classification}

M31

\section{Introduction}

"Information and Communication Technology" (ICT) is one of those sectors with huge development potential, this being evidenced by the statistics indicators, and in the same time constituting both development objective of national and European strategies and programs.

Thus, the "promotion of the 10 sectors of the future", identified as the economic sectors with the potential of smart development, is one of the priorities set out in National Competitiveness Strategy 2014 - 2020. Among the 10 identified sectors is included the "Information and Communication Technology ".

As we stated earlier, ICT support is a priority at European level. Thus, under the EU Cohesion Policy for the period 2014 - 2020, drafted by the European Commission, represents a necessity directing the investments towards four key areas for economic growth and jobs creation, here including the ICT; achieving the strategic objectives assumes among other things: "Continuing the transition to innovative uses of ICT by businesses, citizens and public administrations, such as the provision of electronic services in health (eHealth), in the public sector (e-government), in SMEs (e-learning, e-business), coordination of resource efficiency in urban areas (Smart Cities) and preservation of cultural heritage through digitization, enhancing digital literacy, elearning, e-inclusion and related entrepreneurial e-skills ".

\section{Contribution of "Information and communications" branch in achieving macroeconomic indicators}

According to data for the period 2010-2014, in Romania, the contribution of ICT to macroeconomic indicators (gross added value to the national economy) grew from $4.9 \%$ to $6.6 \%$. This increase occurred on a background of positive developments in 
the total gross added value of all industries, the dynamics registered by "Information and Telecommunications" (+ 58.4\% in 2014 compared to 2010), outpacing the average in the national economy ( $+17 \%$ in 2014 compared to 2010). (Table 1 and Fig. 1)

Table 1. Gross added value in the total national economy and in the "Information and communications" branch in the period 2010-2014

\begin{tabular}{|l|c|c|c|c|c|}
\hline \multicolumn{1}{|c|}{ Indicator } & $\mathbf{2 0 1 0}$ & $\mathbf{2 0 1 1}$ & $\mathbf{2 0 1 2}$ & $\mathbf{2 0 1 3}$ & $\mathbf{2 0 1 4}$ \\
\hline $\begin{array}{l}\text { Gross value added - total } \\
\text { activities (mil. euro) }\end{array}$ & 113249.3 & 116966.4 & 117125.1 & 127043.1 & 132553.8 \\
\hline $\begin{array}{l}\text { Gross value added - } \\
\text { "Information and } \\
\text { communication" activities } \\
\text { (mil. euro) }\end{array}$ & 5551.5 & 5573.4 & 5326.9 & 7126.0 & 8793.3 \\
$\begin{array}{l}\text { \% Gross value added from } \\
\text { Information and } \\
\text { communication in total } \\
\text { Gross value added }\end{array}$ & 4.9 & 4.8 & 4.5 & 5.6 & 6.6 \\
\hline
\end{tabular}

Source: taken and processed from Eurostat

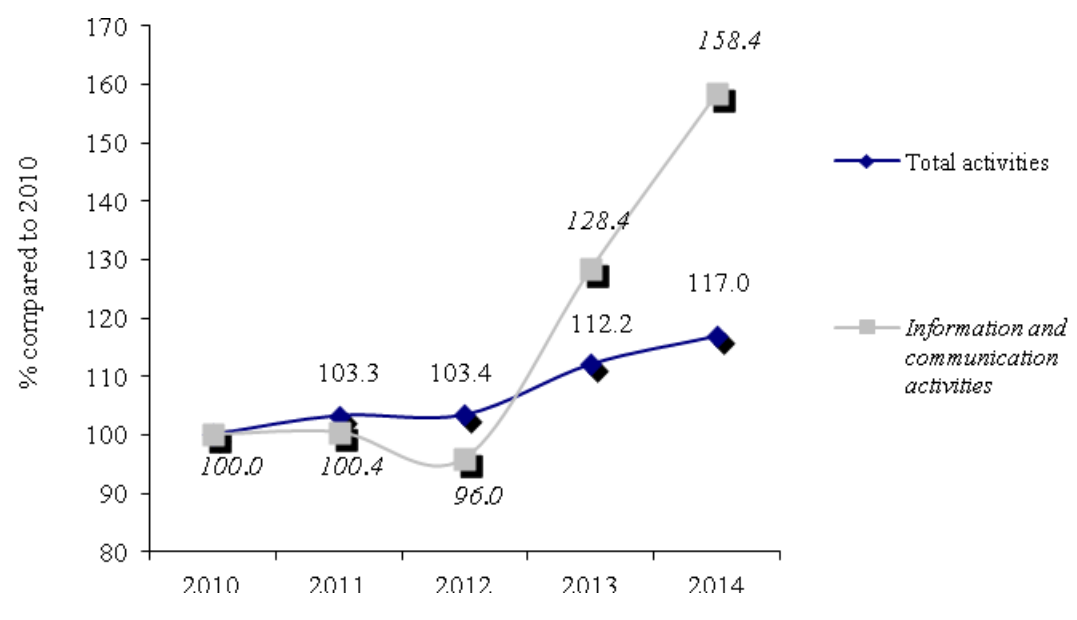

Figure 1. Dynamics of total gross added value in the national economy and in the branch of "Information and Telecommunications" in the period 2010-2014 (\% compared to 2010)

Source: taken and processed from Eurostat

Evolution of employment in the sector "Information and communications"

Similar to results indicators, the employment in the industry of "Information and communication" has raised during 2010 - 2014 by over 20\%, which contributed to the growth of this sector in total employment in Romania (from 2\% in 2010, to 2.3\% in 2014). (Table 2 and Fig. 2) 
Table 2. Employees in total national economy and in the branch of "Information and communications" in the period 2010-2014

\begin{tabular}{|l|c|c|c|c|c|}
\hline \multicolumn{1}{|c|}{ Indicator } & $\mathbf{2 0 1 0}$ & $\mathbf{2 0 1 1}$ & $\mathbf{2 0 1 2}$ & $\mathbf{2 0 1 3}$ & $\mathbf{2 0 1 4}$ \\
\hline $\begin{array}{l}\text { Employees - Total activities } \\
\text { (Thousand) }\end{array}$ & $5,643.8$ & $5,690.6$ & $5,726.3$ & $5,737.2$ & $5,841.3$ \\
\hline $\begin{array}{l}\text { Employees - "Information } \\
\text { and communication" } \\
\text { activities (Thousand) }\end{array}$ & 111.1 & 115.7 & 131.2 & 132.0 & 135.0 \\
\hline $\begin{array}{l}\text { \% Employees from } \\
\text { Information and } \\
\text { communication in total } \\
\text { Employees }\end{array}$ & 2.0 & 2.0 & 2.3 & 2.3 & 2.3 \\
\hline
\end{tabular}

Source: taken and processed from Eurostat

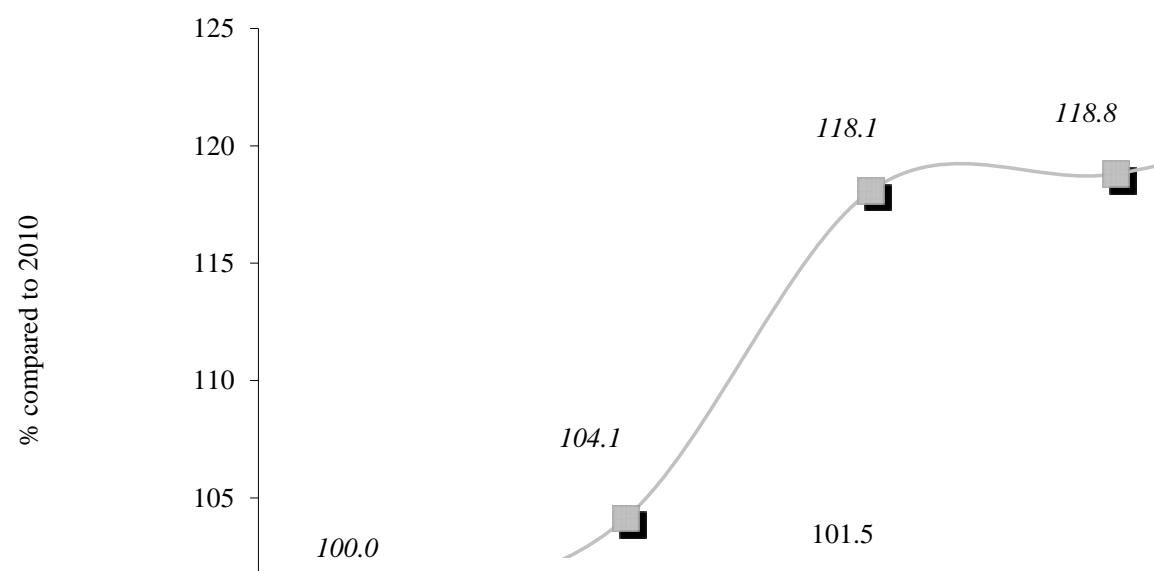

Figure 2. Employees in total national economy and in the branch of

"Information and communications" in the period 2010-2014

Source: taken and processed from Eurostat

\section{Sales development in the national IT market}

Based on information derived from a study conducted by GfK, sales of IT equipment in recent years (2010 - 2014) had an upward trend, in annual average increase being about 8\% (Table 3)

Table 3. Evolution of IT equipment sales in the period $2008-2014$

\begin{tabular}{|c|c|c|c|c|c|}
\hline Year & $\mathbf{2 0 1 0}$ & $\mathbf{2 0 1 1}$ & $\mathbf{2 0 1 2}$ & $\mathbf{2 0 1 3}$ & $\mathbf{2 0 1 4}$ \\
\hline $\begin{array}{c}\text { IT equipment sales (mil. } \\
\text { euro) }\end{array}$ & 338 & 427 & 432 & 455 & 455 \\
\hline
\end{tabular}

Source: GFK 

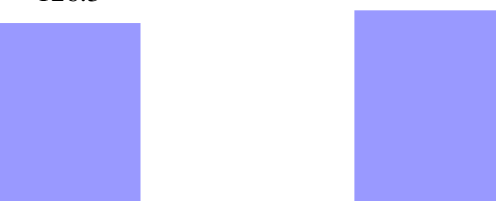

Figure 3. Dynamics of IT equipment sales in the period 2010-2014 (\% compared to 2010)

Source: own computation from GFK

Production of IT equipment fall within NACE division "Manufacture of computer, electronic and optical products". According to Table 4 there is a decrease in recent years (for which we have official data) of the specific results of this division, which, in the context of increasing sales of IT equipment, highlights the lack of local attractiveness and appropriateness of the activity (production of hardware) compared to other activities related (operating in the same NACE division).

Table 4. Evolution of turnover in the sector "Manufacture of computer, electronic and optical products" in the period $2010-2013$

\begin{tabular}{|c|c|c|c|c|}
\hline Year & $\mathbf{2 0 1 0}$ & $\mathbf{2 0 1 1}$ & $\mathbf{2 0 1 2}$ & $\mathbf{2 0 1 3}$ \\
\hline Turnover (thousands lei) & 12056543 & 11332789 & 7314076 & 6993454 \\
\hline
\end{tabular}

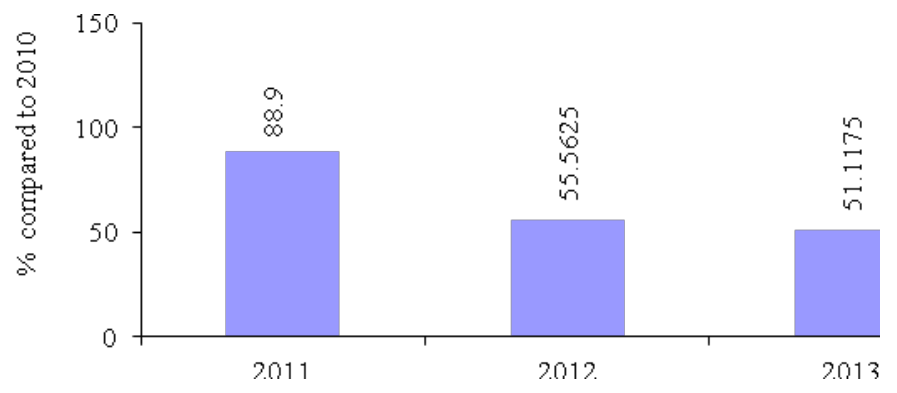

Figure 4. Dynamics of turnover of the sector "Manufacture of computer, electronic and optical products" in the period 2010-2014 (\% compared to previous year)

Source: own processing after Results and performance of enterprises in industry and construction, 2012, 2013, 2014, 2015, National Institute of Statistics

Regarding the software and IT services market, its dynamic outpaced the growth recorded by sales of IT equipment. Thus, between 2011 - 2014, according to a study by Pierre Audoin Consultants commissioned by the Employers' Association of the 
Software and Services Industry, sales of software and IT services grew by almost 50\%. (Table no. 5)

Estimates for the coming years, according to the same sources, indicate market growth up to 3782 mil. Euro in 2018, which basically means an average annual increase of about $12 \%$.

Table 5. Sales development of software and IT services in the period 2011 -2014

\begin{tabular}{|c|c|c|c|c|}
\hline Year & $\mathbf{2 0 1 1}$ & $\mathbf{2 0 1 2}$ & $\mathbf{2 0 1 3}$ & $\mathbf{2 0 1 4}$ \\
\hline $\begin{array}{c}\text { Software and IT } \\
\text { services sales (mil. } \\
\text { Euro) }\end{array}$ & 1644 & 1877 & 2152 & 2421 \\
\hline
\end{tabular}

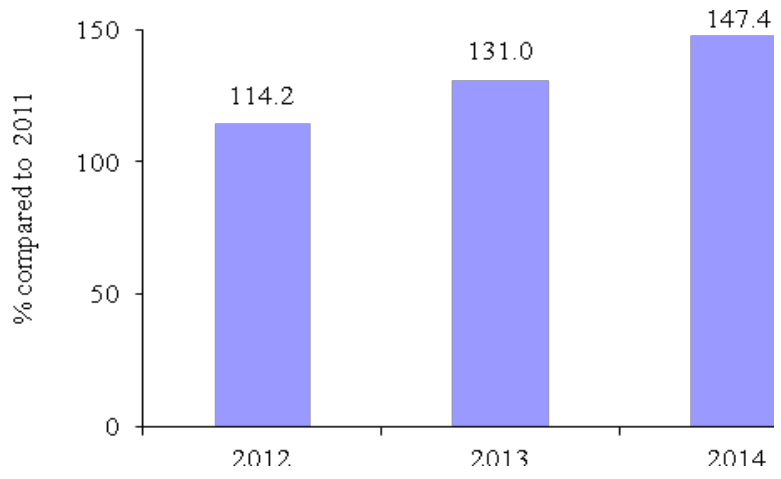

Figure 5. Dynamics of sales of software and IT services in the period 2011 -2014 (\% compared to 2011)

Source: own computation after Pierre Audoin Consultants

The expansion of the IT market can be highlighted based on both economic indicators presented above (gross added value and employment in the branch "Information and communications", sales), and based on indicators confirming the access people and organizations to technology, implicitly reflecting the social dimension of the analyzed sector, highlighting the orientation of the entire society toward computerization.

Referring to the population's access to technology, according to data from Eurostat, in $2014,60 \%$ of the population of 16-74 years used the computer. Although we are far below the European average (79\% in EU), it is established that the indicator followed an upward trajectory, so that during the period from 2010 to 2014 there was an increase of over $30 \%$. Subscribing to the same trend, Internet access of households in Romania also increased, from 42\% in 2010 to $61 \%$ in 2014. 


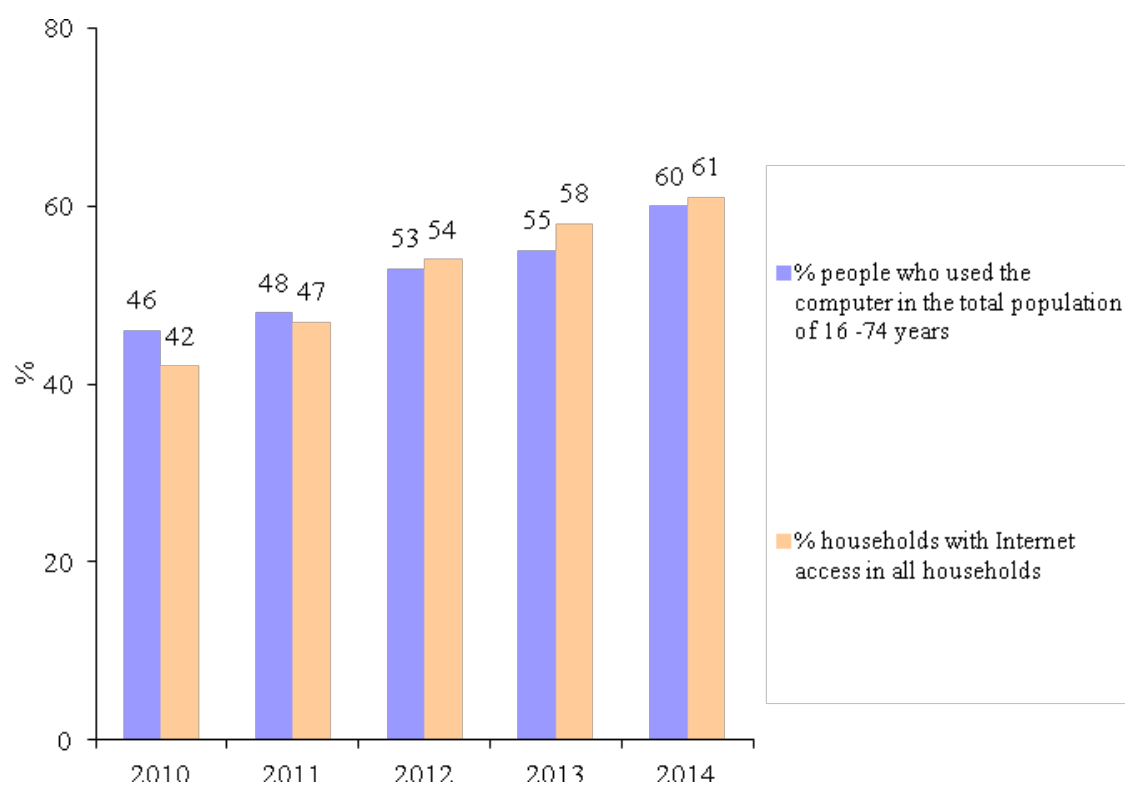

Figure 6. Share of people who used the computer in the total population of 16-74 years in Romania and the share of households with Internet access in Romania during 2010-2014

Source: Eurostat

Also, public expenditures for the purchase of equipment to process information and accessories rose by almost $70 \%$ over the past 4 years.
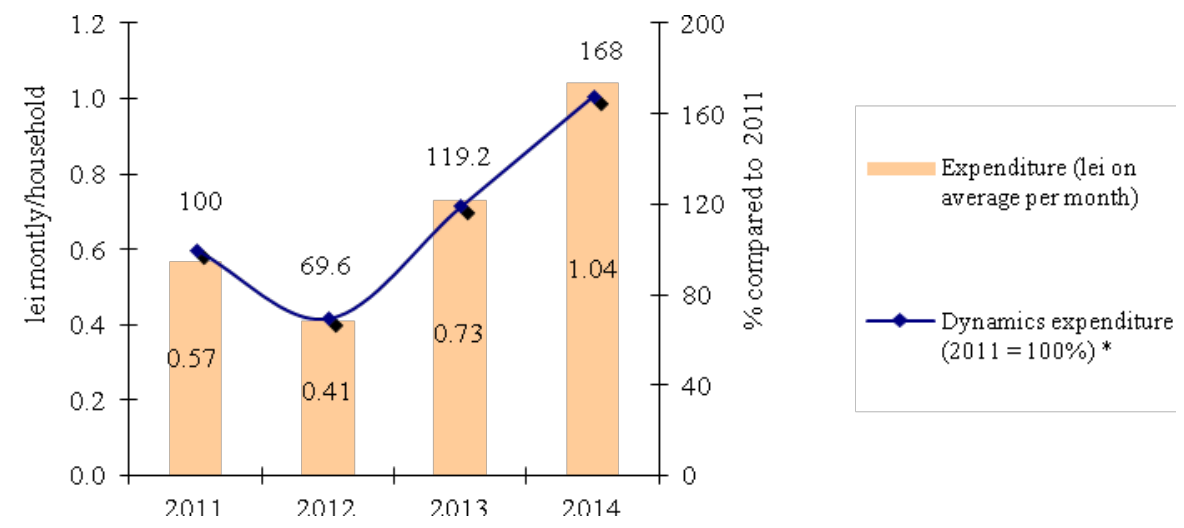

Figure 7. Evolution of public expenditure for the purchase of computing equipment and accessories during 2011-2014

Source: Coordinates of living in Romania. Income and consumption, 2011-2014, INS

* own processing based on average annual CPI from INS 
Referring to organizations' access to technology, according to available data provided by Eurostat, the proportion of organizations in Romania (organizations with over 10 employees, excluding the financial sector) that have computer was in 2014 87\% (in recent years the progress of the indicator being positive). In connection with the above indicator and recording the same trajectory, the share of enterprises (organizations with over 10 employees, excluding the financial sector) who had Internet access in 2014 amounted 85\%. Relating to the EU average (97\% of businesses had computers and as many had Internet access in 2014) we see that Romania is below the EU average in terms of the use of computer and Internet access of the organizations.

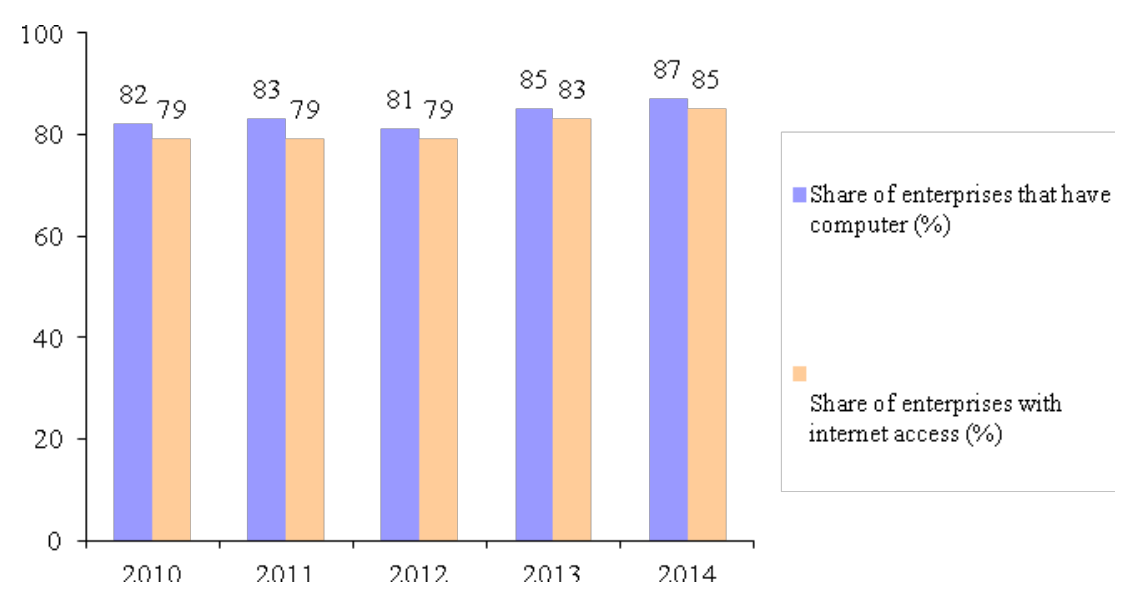

Figure 8. Share of enterprises in Romania in all enterprises (with over 10 employees, excluding the financial sector) that have a computer and had access to the Internet during 2010-2014

Source: Eurostat

In conclusion, indicators that show IT market developments in Romania registered an upward trend, highlighting thus the expanding sectors of hardware, software and IT services. Market dynamics has been highlighted by sales trends, by the increased use of information technology by organizations and population, and by the increasing contribution of the branch of "Information and communication" in achieving national macroeconomic indicators.

\section{References}

Coordonate ale nivelului de trai în România. Veniturile şi consumul populaţiei, 2011, 2012, 2013, 2014, Institutul Naţional de Statistică.

Rezultate şi performanţe ale intreprinderilor din industrie şi construcţii, 2011, 2012, 2013, 2014, 2015, Institutul Naţional de Statistică.

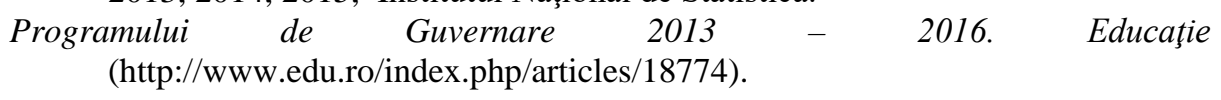


Politica de coeziune a UE în perioada 2014 - 2020, Comisia Europeană (http://ec.europa.eu/regional_policy/sources/docgener/informat/2014/fiche_ict _ro.pdf).

Recomandarea 2006/962/CE a Parlamentului European şi a Consiliului din 18 decembrie 2006

(http://ecalificat.ro/uploads/files/productsitems/0/RECOMANDARE_A_PAR LAMENTULUI_EUROPEAN_SI_A_CONSILIULUI_EUROPEI_Privind_co mpetentele_cheie.pdf).

România - Strategia Naţională pentru Competitivitate 2014-2020, Ministerul Economiei (http://www.minind.ro).

Industria românească de software şi servicii IT: 2.5 mld euro in 2014, 3.7 mld euro in 2018, Blogul industriei software din România (https://programatinromania.wordpress.com).

Studiu: Industria de software şi servicii IT a crescut cu 13\% în 2014, ajungând la venituri de 2,42-mld. Euro, Asociaţia Patronală a Industriei de Software şi Servicii - ANIS (http://www.anis.ro).

Top 15 cele mai mari firme de soft, servicii şi soluţii de IT după afacerile din 2014, Ziarul financiar (www.zf.ro).

Vânzările de echipamente electro-IT au trecut de 2 mld. euro pentru prima oară după 2008, Ziarul financiar (www.zf.ro).

Eurostat, available at http://ec.europa.eu/eurostat/data/database.

Institutul Naţional de Statistică - Tempo-online, Indicele preţurilor de consum (www.insse.ro). 